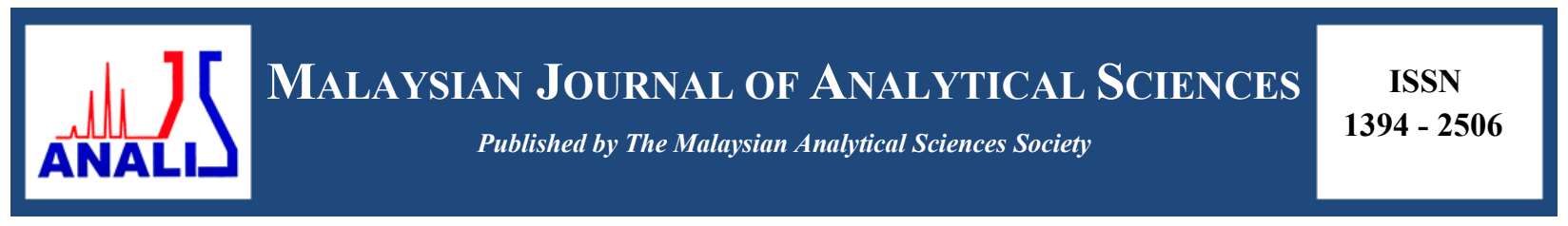

\title{
EXTRACTION AND CHARACTERIZATION OF CELLULOSE FROM AGRICULTURAL RESIDUE - OIL PALM FRONDS
}

\section{(Pengekstrakan dan Pencirian Selulosa daripada Bahan Buangan Pertanian - Pelepah Kelapa Sawit)}

\author{
Siti Rasila Ainaa Mohd Rasli ${ }^{1}$, Ishak Ahmad², Azwan Mat Lazim², Ainon Hamzah ${ }^{1}$ * \\ ${ }^{1}$ School of Biosciences and Biotechnology, Faculty of Science and Technology \\ ${ }^{2}$ School of Chemical Sciences and Food Technology, Faculty of Science and Technology \\ Universiti Kebangsaan Malaysia, 43600 UKM Bangi, Selangor, Malaysia \\ *Corresponding author: ainonh@gmail.com
}

Received: 4 March 2017; Accepted: 22 August 2017

\begin{abstract}
Cellulose from oil palm fronds (OPF) was extracted using a cost-effective method combining physical treatment (high pressure steaming) and repeated chemical treatments (alkali and bleaching). Alkali and bleaching treatments were performed using low concentrations of sodium hydroxide and sodium chlorite, respectively. High levels of cellulose were successfully extracted, with 4 grams of cellulose for every 10 grams of raw oil palm fronds. The morphology of the cellulose was investigated using variable pressure scanning electron microscope (VPSEM). Fourier transform infrared spectroscopy (FTIR), X-ray diffraction (XRD) and thermogravimetric analyser (TGA) were used for structural analysis. The extracted cellulose was found to have smaller diameter $(8-10 \mu \mathrm{m})$ and smoother surface compared to the untreated fibres. The results from FTIR, XRD and TGA indicate that the hemicelluloses and lignin were extensively removed from the isolated cellulose. Alkali treatment helped in removal of hemicelluloses, while bleaching assisted in delignification. The extracted cellulose showed high crystalline index of $68.75 \%$ and degradation temperature of $350{ }^{\circ} \mathrm{C}$ resulted from removal of lignin and hemicelluloses via alkali and bleaching treatments.
\end{abstract}

Keywords: Elaeis guineensis, high pressure steaming, alkali treatment, bleaching treatment, cellulose

\section{Abstrak}

Selulosa telah diekstrak daripada pelepah kelapa sawit dengan menggunakan kaedah yang menjimatkan kos iaitu gabungan kaedah fizikal (pemanasan pada tekanan tinggi) dan rawatan kimia (alkali dan pelunturan). Rawatan alkali dilakukan dengan menggunakan sodium hidroksida manakala rawatan pelunturan pula dilakukan dengan menggunakan sodium klorit. Kedua-dua bahan kimia tersebut digunakan pada kepekatan yang rendah. Sebanyak 4 gram selulosa berjaya diekstrak daripada setiap 10 gram pelepah kelapa sawit. Morfologi selulosa yang diekstrak telah dikaji dengan menggunakan mikroskopi elektron pengimbas tekanan berubah-ubah (VPSEM). Manakala spektroskopi inframerah transformasi Fourier (FTIR), analisis belauan sinar-X (XRD) dan analisis termogravimetri (TGA) telah digunakan bagi tujuan menganalisis struktur selulosa. Selulosa yang diekstrak mempunyai diameter yang lebih kecil $(8-10 \mu \mathrm{m})$ dan permukaan yang lebih licin berbanding gentian yang tidak dirawat. Hasil daripada FTIR, XRD dan TGA menunjukkan bahawa hemiselulosa dan lignin telah dibuang dalam jumlah yang tinggi selepas rawatan-rawatan tersebut dijalankan. Rawatan alkali membantu membuang hemiselulosa manakala rawatan pelunturan pula membantu membuang lignin daripada sampel. Selulosa yang diekstrak mempunyai tahap kristal yang tinggi iaitu $68.75 \%$ dan suhu degradasi yang tinggi iaitu $350{ }^{\circ} \mathrm{C}$ berikutan daripada pembuangan hemiselulosa dan lignin selepas rawatan alkali dan pelunturan dilakukan.

Kata kunci: Elaeis guineensis, pemanasan pada tekanan tinggi, rawatan alkali, rawatan pelunturan, selulosa 


\section{Siti Rasila Ainaa et al: EXTRACTION AND CHARACTERIZATION OF CELLULOSE FROM \\ AGRICULTURAL RESIDUE - OIL PALM FRONDS}

\section{Introduction}

Elaeis guineensis, commonly known as oil palm, is one of the main crops in Malaysia and is widely planted all over the country, especially in Sabah, Sarawak and Johor. With oil palm covering about 4.49 million hectares. Malaysia is the world's second largest palm oil exporter, accounting for $39 \%$ of the world palm oil production [1]. The oil palm plantation industry contributes to huge amount of agricultural wastes (lignocellulosic biomass) every year such as the OPFs from thinning, replanting and pruning processes. The huge amounts of waste generated from the oil palm industry have led to concerns over the managements of the wastes. The most common disposal methods for such agricultural waste include use in mulching or leaving it to decompose naturally in the plantation area. These practices are harmful to the environment. The decomposing OPFs interfere with plantation processes and serve as pest breeding sites [2], especially for insects like rhinoceros beetles.

Natural plant fibres are made up of cellulose, amorphous polymers (hemicelluloses and lignin) and small number of extractives. Cellulose is a naturally occurring hydrophilic polymer and is the main substance that makes up plant cell walls and contributes to the physical stability of the cells [3]. Thus, cellulose is probably the most abundantly available organic compound on Earth. Cellulose does not dissolve in water, and has high crystallinity and high molecular weight [4].

The OPFs are composed of 58\% cellulose, $24 \%$ hemicelluloses, $5 \%$ lignin, $8 \%$ extractives and $5 \%$ ashes [5]. The amount of cellulose in the OPF is higher than other waste parts (leaves and empty fruit bunches) of oil palm trees [6].

The accumulating amount of the agricultural waste or OPFs could serve as an inexpensive cellulose source compared to wood, that could be exploited for many uses and purposes. The common uses of cellulose are in paper, film, textiles, building material and food additives production. Recent studies have shown strong interest in this organic polymer due to its superior characteristics, such as high water absorption capacity [7] and large surface areas, compared to other biomaterials. Besides the traditional uses of cellulose, some of the latest cellulose-based innovations are focusing on solving environmental problems, such as cellulose-based absorbents for oil spills and heavy metal pollution on water or land [8]. Additionally, there have been studies on the uses of cellulose in biobased filters for industrial [9] and municipal wastewater treatment [10].

The extraction of cellulose from oil palm fronds using an inexpensive method could serve as an alternative environmental friendly way of managing the largely produced agricultural wastes. The purpose of this study was to extract the cellulose from oil palm fronds using a cost-effective method, namely a combination of physical and chemical methods. The physical method used was the high pressure steaming, while the chemical methods were alkali and bleaching treatments. Then, the extracted cellulose was characterized using a variable pressure scanning electron microscope (VPSEM), Fourier transmission infrared (FTIR), thermogravimetric analyser (TGA), and X-ray diffraction (XRD).

\section{Materials}

\section{Materials and Methods}

Fresh Oil Palm Fronds (OPFs) were collected from the MPOB (Malaysian Palm Oil Board), Bangi, Selangor. The chemical reagents used were sodium hydroxide $(\mathrm{NaOH})$ and sodium chlorite $\left(\mathrm{NaClO}_{2}\right)$. To assist in physical treatment, an autoclave (Hirayama, HVE50) was used.

\section{Pre-treatment}

The collected OPF were cut into smaller pieces $(15-20 \mathrm{~cm})$ before dried at room temperature for 3 days. The dried OPFs were then ground into smaller size of $5-6 \mathrm{~cm}$ and soaked in water for 3 days. The water was changed daily. The samples were then rinsed with distilled water several times to remove dirt and sand particles. Then, the samples were autoclaved at $121^{\circ} \mathrm{C}, 21 \mathrm{psi}$ for 15 minutes. The dark brown supernatant was removed and the samples were washed with distilled water a few times until clear water was observed. The OPFs were dried at room temperature and ground into $1-2 \mathrm{~cm}$ pieces. 


\section{Extraction of OPF-cellulose}

Cellulose extraction from OPF was done using the method from Chan et al. [11] with some modifications. The autoclaved and dried samples were treated with $4 \%$ sodium hydroxide $(\mathrm{NaOH})$ at $80{ }^{\circ} \mathrm{C}$ for 2 hours with continuous stirring. Then, a bleaching treatment was applied using $1.7 \%$ sodium chlorite $\left(\mathrm{NaClO}_{2}\right)$ at $\mathrm{pH} 4.5$ and $80{ }^{\circ} \mathrm{C}$ for 4 hours with continuous stirring. The alkali and bleaching treatments were repeated three and four times, respectively. The ratio of sample to solvent was $5: 100(\mathrm{~g} / \mathrm{mL})$. After each treatment, the samples were rinsed few times using distilled water. The extracted cellulose was dried in an oven at $60{ }^{\circ} \mathrm{C}$ and the dried weight of the cellulose was determined.

\section{Characterization: Variable pressure scanning electron microscope}

The morphological studies of extracted cellulose from OPF were carried out with a variable pressure scanning electron microscope (Leo 1450VP/ Zeiss)

\section{Fourier transmission infrared spectroscopy}

The chemical investigation of functional groups in extracted cellulose from OPF was done using Fourier Transmission Infra-Red Spectroscopy (Perkin Elmer Spectrum 400 FT-IR/FT-NIR and Spotlight 400 Imaging System).

\section{X-ray diffraction}

The crystallinity of the extracted cellulose was studied using an X-ray diffractometer (Bruker/D8 Advance). The crystalline index was determined based on the method by Segal [12] using the following equation:

$$
\mathrm{X}_{\mathrm{c}}=\frac{I_{002}-I_{a m}}{I_{002}} \times 100
$$

where $\mathrm{X}_{\mathrm{c}}$ is the crystalline index, $I_{002}$ is the peak intensity of crystalline materials and $I_{\mathrm{am}}$ is the peak intensity of amorphous materials.

\section{Thermogravimetric analysis}

Thermogravimetric analysis was carried out using Mettler Toledo thermogravimetric analyser (TGA/SDTA 85-F) to measure the thermal stability of all samples. Measurements were made with a nitrogen gas flow of $10 \mathrm{~mL} \mathrm{~min}{ }^{-1}$ and heated from room temperature to $600{ }^{\circ} \mathrm{C}$ with heating rate of $10{ }^{\circ} \mathrm{C} \mathrm{min}{ }^{-1}$.

\section{Extraction of OPF-cellulose}

\section{Results and Discussion}

The combination of physical and chemical methods succeeded in extracting high total cellulose yield, $40 \%(\mathrm{w} / \mathrm{w})$ on a dry weight basis. The pre-treatment of samples by high pressure steaming played a role in removing loose substances from the surface of the fibres and assisted in penetration of the alkali and bleaching reagents by reducing the polymerization degree of the fibres.

\section{Morphological analysis}

The colour of the raw oil palm frond fibres changed from brown to white after treatment (Figure 1). The extracted cellulose fibres had smaller diameters $(8-10 \mu \mathrm{m})$ and smoother surfaces compared to the untreated fibres, which had diameters ranging from 150 to $300 \mu \mathrm{m}$ and rough surfaces (Figure 2).

Both colour and morphological changes were due to removal of lignin and other extractives during high pressure steaming and bleaching treatments, resulting in lighter colour and smoother surface of the fibres, respectively. The colour of wood is determined by the phenolic substances (lignin and extractives). The removal of extractives caused a slight colour change, while removal of lignin caused a more significant colour change [13]. The removal of the binding substance also induced the dispersal of the fibre bundles into individual fibres by cleavage of the bonds between the hemicelluloses and lignin, producing fibres with smaller diameters. A smoother surface of the extracted cellulose resulted from all the treatments (high pressure steaming, alkali and bleaching treatments) which removed impurities from the surface of the fibres. 

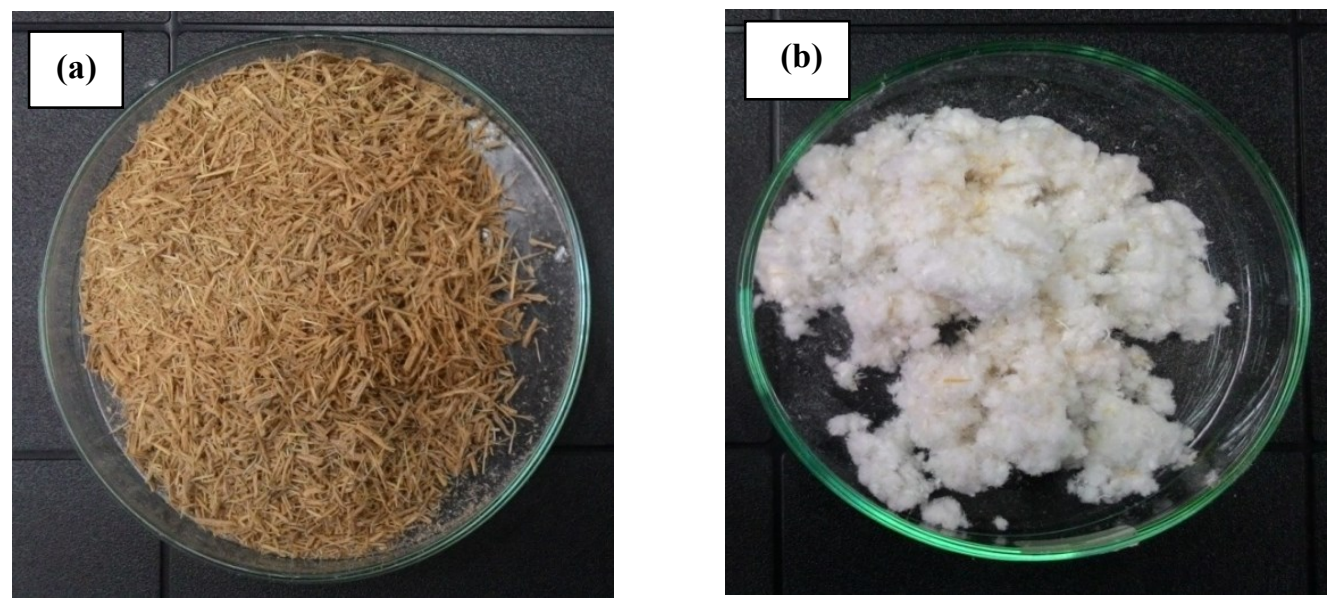

Figure 1. Ground oil palm fronds. (a) Before treatments and (b) after treatments
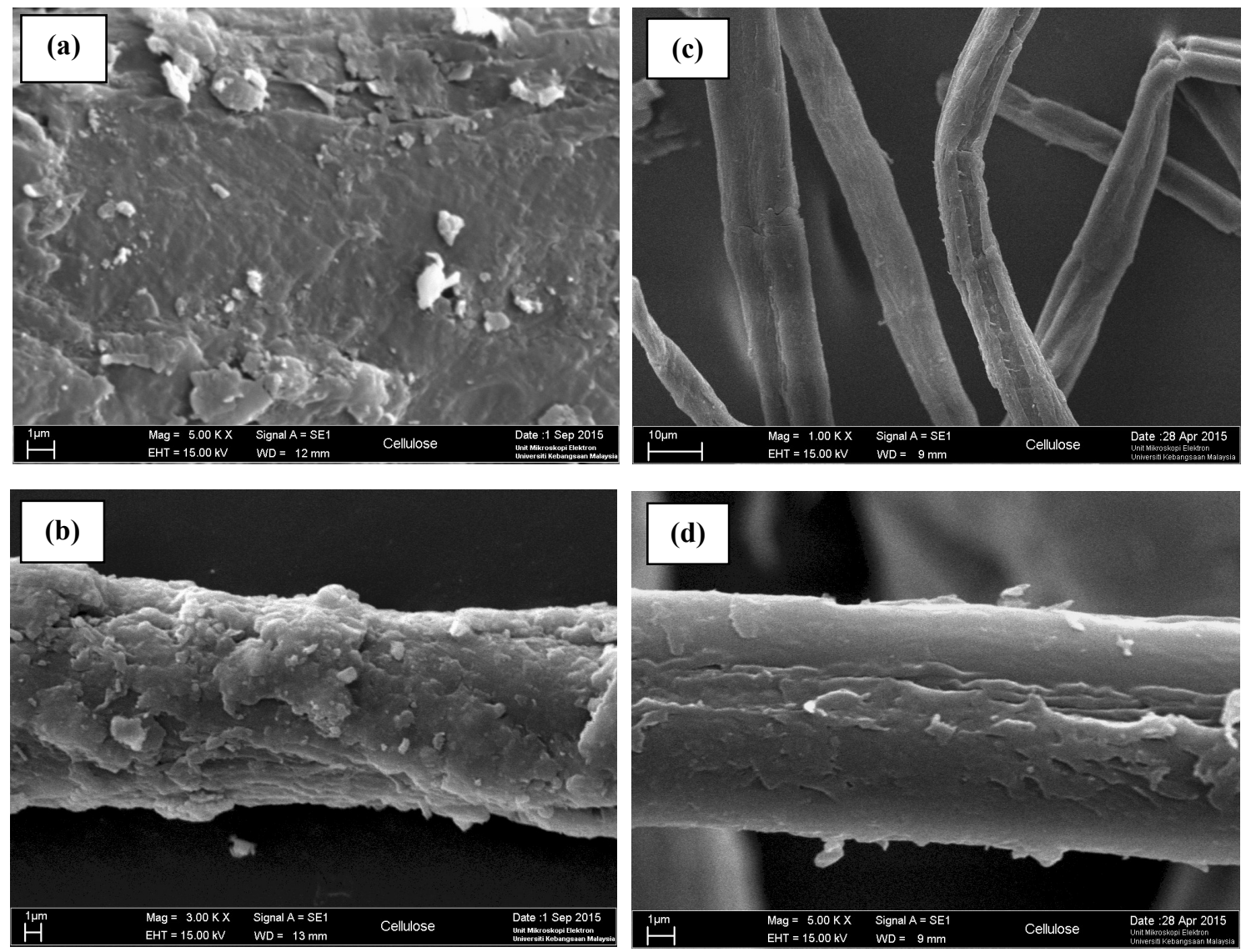

Figure 2. Variable pressure scanning electron microscope micrographs of oil palm frond samples. (a) and (b) before treatments, while (c) and (d) after treatments 


\section{FTIR spectroscopy analysis}

The FTIR results (Figure 3) suggest the complete removal of the functional groups of both lignin and hemicelluloses from the extracted cellulose. The peak $1246.70 \mathrm{~cm}^{-1}$ (C-O-C, aryl-alkyl-ether) which is the ether bond between the hydroxyl groups of lignin and the carbohydrates in the raw OPF was completely removed after alkali treatment. This indicates the complete removal of the hemicelluloses. Meanwhile, the intensity of the peak $1594.81 \mathrm{~cm}^{-1}(\mathrm{C}=\mathrm{C}$ of lignin aromatic ring $)$ was reduced after alkali treatment and completely removed after bleaching. As reported by Johar et al. [14], the alkali treatment removed hemicelluloses and other impurities from the raw samples, while partially removed the cementing material of lignin.

The peaks at $897.86 \mathrm{~cm}^{-1}$ and $3318.87 \mathrm{~cm}^{-1}$ were attributed to the $\beta$-glycosidic linkage of cellulose and adsorbed water in the samples, respectively. The peaks at $2922.03 \mathrm{~cm}^{-1}$ and $1031.86 \mathrm{~cm}^{-1}$ indicate the $\mathrm{C}-\mathrm{H}$ and C-O groups of the cellulose. The high pressure steaming treatment softened the lignin and released it from the cell wall to the fibre surface. This physical treatment played a role in increasing the accessible surface area and size of cell wall pores for penetration of the alkali and bleaching reagents.

The alkali treatment removed hemicelluloses from the sample through hydrolysis of glycosidic bonds in hemicelluloses and led to the cleavage of the ester bonds between the hydroxyl groups of lignin and the carboxyl groups of the hemicelluloses. Hemicelluloses are susceptible to the two degradation reactions by alkali reactions due to the high number of end-groups resulted from low polymerization level. The hemicelluloses were released from the fibres and complete removal was achieved by the repeated washing of the samples with distilled water.

Delignification of the fibres was achieved by complete removal of the lignin on the fibre surface. The lignin was degraded by the bleaching treatments using an oxidising agent, sodium chlorite which oxidized the ether bonds between the hydroxyl groups of lignin and the carbohydrates. The most common chemicals used in bleaching process are hydrogen peroxide, oxygen, and sodium chlorite. Sodium chlorite is the most effective for bleaching without reducing total carbohydrate [15]. Acidified sodium chlorite has been reported to cleave the phenolic ether bonds in plant cell walls at high temperatures [16]. The bleaching treatment also removed remaining hemicelluloses by oxidation reactions that cleaved the glycosidic linkages of the residues [15].

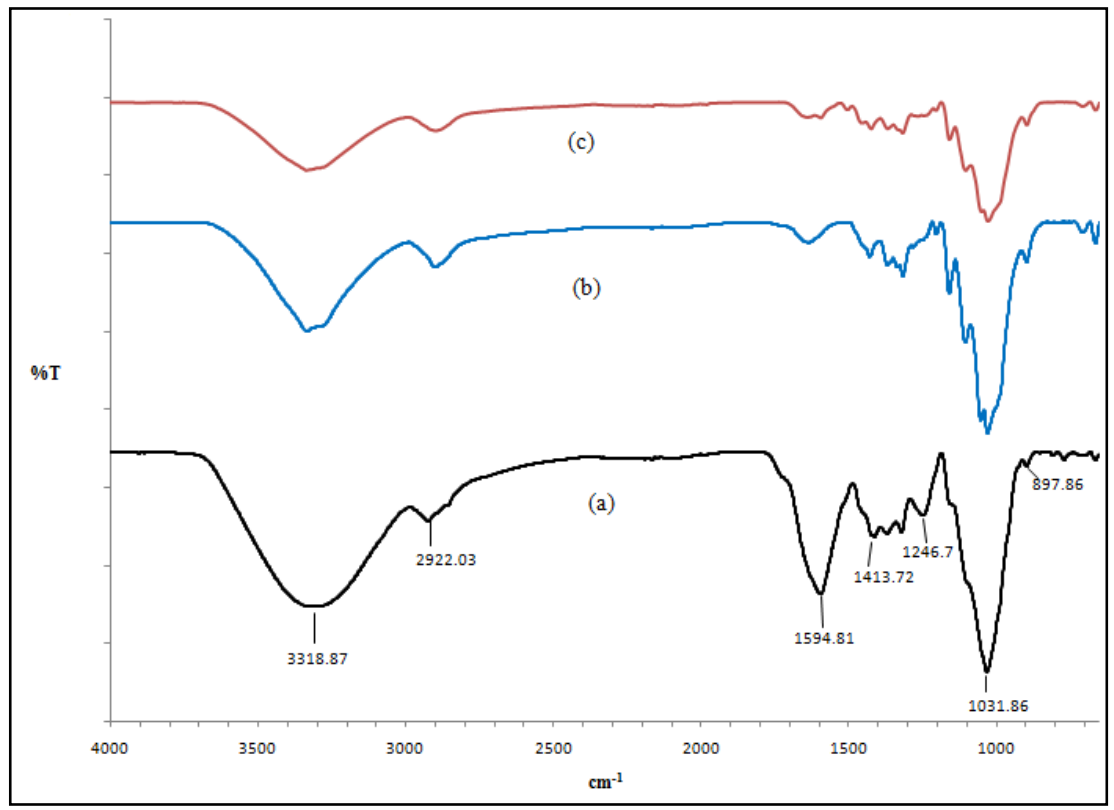

Figure 3. Fourier transmission infrared spectroscopy spectra of the extracted cellulose from oil palm fronds:

(a) raw oil palm frond, (b) after alkali treatment and (c) after bleaching treatment 


\section{X-ray diffraction measurements}

Cellulose is made of diverse crystalline arrangements which result from the hydrogen bonding of the hydroxyl groups. The major peaks $\left(22.6^{\circ}\right)$ in the X-ray diffractogram are attributed to the crystalline structure of the cellulose, while the low intensity at $18^{\circ}$ reflects the amorphous background of the samples.

X-ray diffraction results (Figure 4) show a crystalline index of $24.31 \%$ for the raw oil palm fronds, which progressively increased after alkali treatment $(52.46 \%)$ and bleaching treatment $(68.75 \%)$. The crystalline index values of all samples are listed in Table 1. The increasing crystalline index of the samples after alkali and bleaching treatments were due to progressive removal of the hemicelluloses and lignin. According to Sheltami et al. [17], the crystallinity level of cellulose is influenced by removal of amorphous polymers.

The crystalline index of the extracted cellulose is higher compared to the $57.19 \%$ reported by Syamani et al. [18] for the extracted cellulose from oil palm fronds by pulping and bleaching using hydrogen peroxide. The amount of cellulose is higher due to higher removal of the amorphous polymers via alkali and sodium chlorite bleaching treatments. In addition, the major peaks progressively became sharper after each treatment, reflecting the greater distinguished crystalline structure of the samples.

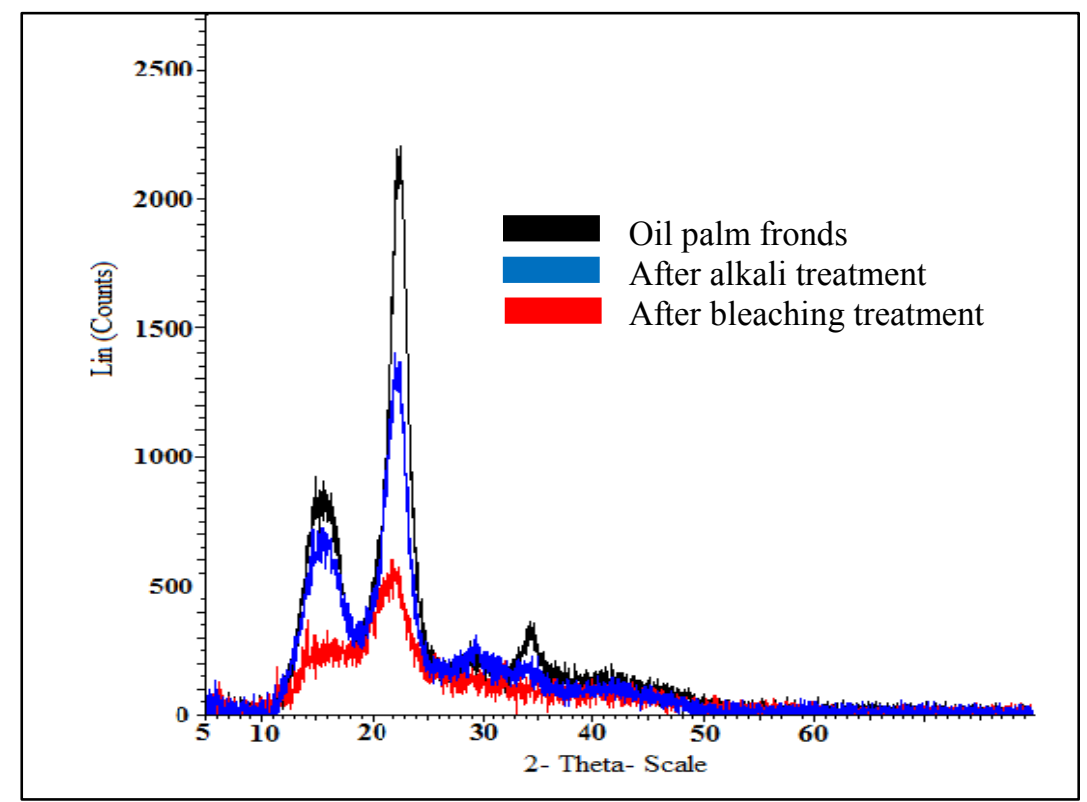

Figure 4. X-ray diffraction patterns for raw oil palm frond, after alkali treatment and after bleaching treatment

Table 1. Crystalline index of the oil palm fronds at different stages of treatment

\begin{tabular}{lccc}
\hline Samples & $\mathbf{2 \theta ( a m )}\left(\boldsymbol{(}^{\mathbf{})}\right.$ & $\mathbf{2 \theta ( 0 0 2 )}\left(\boldsymbol{(}^{\mathbf{}}\right)$ & $\mathbf{X c}(\mathbf{\%})$ \\
\hline Oil palm fronds & 18.5 & 22 & 24.31 \\
After alkali treatment & 18.8 & 22.5 & 52.46 \\
After bleaching treatment & 18.5 & 22.2 & 68.75 \\
\hline
\end{tabular}




\section{Thermogravimetric analysis}

Both TG (Figure 5) and DTG curves (Figure 6) showed the thermal stability of the raw, alkali-treated and bleached samples. All three samples showed initial weight loss at temperature lower than $100{ }^{\circ} \mathrm{C}$ which attributed to the water evaporation from the samples which was the moisture adsorbed to the fibre. After bleaching, weight reduction increased due to the hydrophilic nature of the cellulose, which had a higher level of moisture compared to the raw and alkali-treated samples.

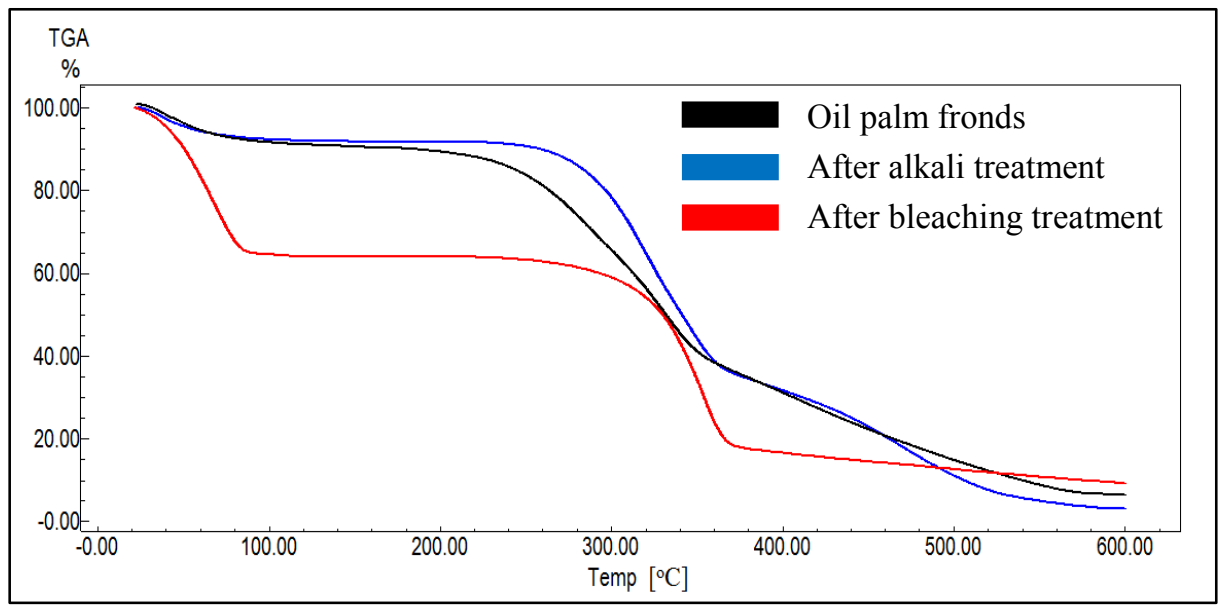

Figure 5. Residual mass (TG) curves of raw oil palm frond, after alkali treatment and after bleaching treatment

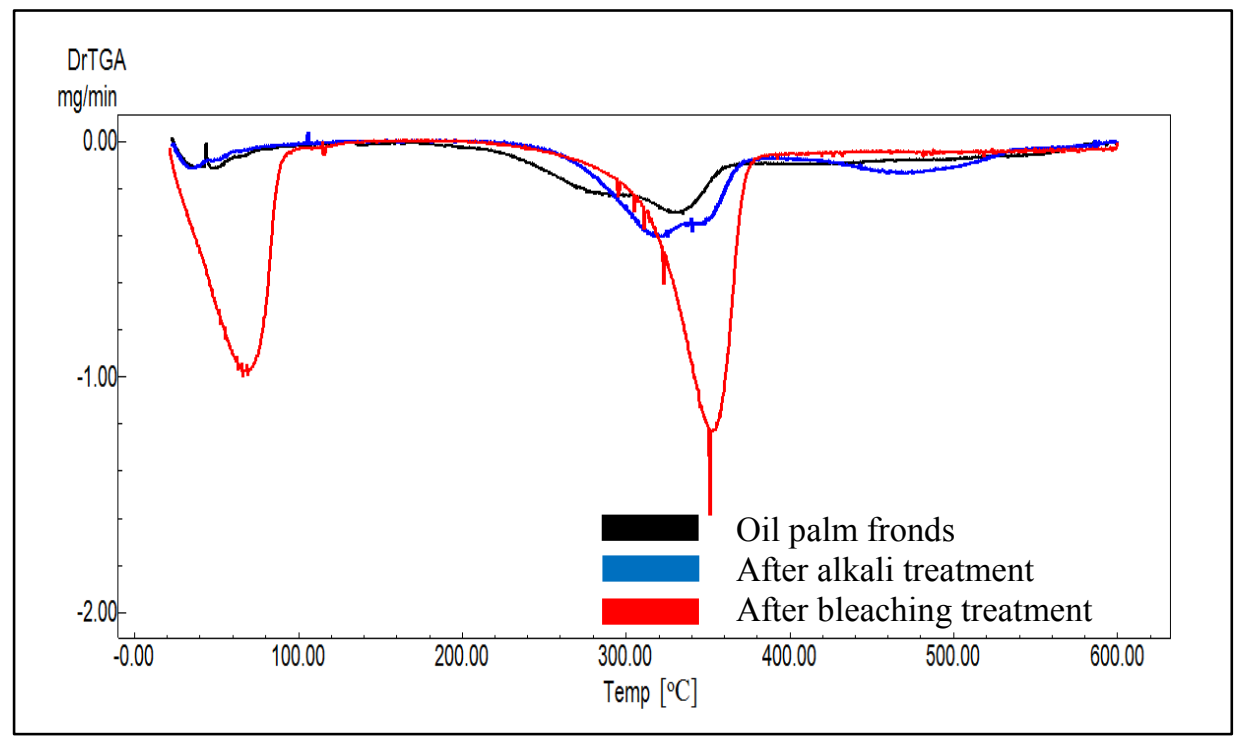

Figure 6. Differential residual mass (DTG) curves of raw oil palm frond, after alkali treatment and after bleaching treatment 


\section{Siti Rasila Ainaa et al: EXTRACTION AND CHARACTERIZATION OF CELLULOSE FROM AGRICULTURAL RESIDUE - OIL PALM FRONDS}

For the raw and alkali-treated samples, there were small broad peaks at $280{ }^{\circ} \mathrm{C}$ and $320{ }^{\circ} \mathrm{C}$ before the major peak, reflecting the low molecular weight compounds, hemicelluloses and lignin [19]. These peaks were completely removed after bleaching treatment.

The major peaks of the DTG curves demonstrate the degradation temperatures of the samples. The bleached sample showed highest degradation temperature at $350{ }^{\circ} \mathrm{C}$ compared to the raw and alkali-treated samples, which degraded at $330{ }^{\circ} \mathrm{C}$ and $345^{\circ} \mathrm{C}$ respectively. The progressively increased degradation temperature of the samples after each treatment was due to the progressive removal of lignin and hemicelluloses. Hemicelluloses and lignin had lower decomposition temperatures compared to cellulose [20]. This was due to the higher crystallinity of the cellulose, which increased the thermal stability of the sample [21].

However, the bleached sample showed highest weight loss at the decomposition temperature. Meanwhile, the raw and alkali-treated samples retained higher residual mass. This was due to the presence of the lignin and ashes within the raw and alkali-treated samples [22]. Ashes were regenerated after the samples were burnt, causing only slight weight reduction of the samples [14]. These thermal analysis results are quite consistent with the results obtained from the FTIR and crystallinity measurements.

\section{Conclusion}

Cellulose was successfully extracted from oil palm fronds using a cost-effective method, with a combination of physical treatment and low concentration chemical methods. High amounts of cellulose $(40 \% \mathrm{w} / \mathrm{w})$ were successfully extracted with a high crystalline index $(68.75 \%)$ and thermal stability $\left(350{ }^{\circ} \mathrm{C}\right)$, demonstrating extensive removal of amorphous polymers from the samples. The extraction of cellulose from the oil palm fronds could be exploited on a larger scale and serve as a proper practice for agricultural waste management. Further research should be carried out to study the mechanical properties of cellulose, including tensile strength and moisture regain, for better understanding on the potential uses of the OPFs cellulose.

\section{Acknowledgement}

The authors would like to express their gratitude to Universiti Kebangsaan Malaysia (GUP-2014-081) for their financial support.

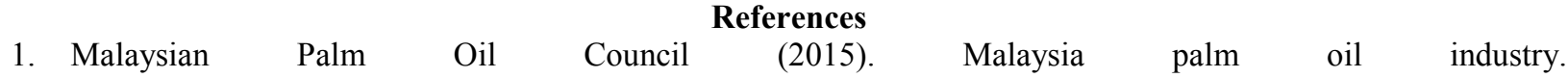
http://www.mpoc.org.my/Malaysia_Palm_Oil_Industry.aspx. [Access online 13 April 2015].

2. Altieri, M. A., Nicholls, C. I. and Fritz, M. A. (2014). Manage insects on your farm. Sustainable Agriculture Research and Education (SARE), Maryland: pp. 15 - 17.

3. Duchemin, B., Thuault, A., Vicente, A., Rigaud, B., Fernandez, C. and Eve, S. (2012). Ultrastructure of cellulose crystallites in flax titles fibres. Cellulose, 19(6): $1837-1854$.

4. Kuutti, L. (2013). Cellulose, starch and their derivatives for industrial applications. VTT Technical Research Centre of Finland, Finland: pp. $35-37$.

5. Sabrina, S. M. S., Roshanida, A. R. and Norzita, N. (2013). Pretreatment of oil palm fronds for improving hemicelluloses content for higher recovery of xylose. Jurnal Teknologi (Sciences \& Engineering), 62(2): 39 42.

6. Sulaiman, O., Salim, N., Nordin, N. A., Hashim, R., Ibrahim, M. and Sato, M. (2012). The potential of oil palm trunk biomass as an alternative source for compressed wood. Bioresources, 7(2): $2688-2706$.

7. Kala, D. R., Rosenani, A. B., Fauziah, C. I., and Thorirah, L. A. (2009). Composting oil palm wastes and sewage sludge for use in potting media of ornamental plants. Malaysian Journal of Science, 13: 77 - 91.

8. Nguyen, S. T., Feng, J., Le, N. T., Le, A. T. T., Hoang, N., Tan, V. B. C. and Duong, H. M. (2013). Cellulose aerogel from paper waste for crude oil spill cleaning. Industrial and Engineering Research, 52: 18386 - 13891.

9. He, Z., Meng, M., Yan, L., Zhu, W., Sun, F., Yan, Y., Liu, Y. and Liu, S. (2015). Fabrication of new cellulose acetate blend imprinted membrane assisted with ionic liquid $((\mathrm{BMIM}) \mathrm{Cl})$ for selective adsorption of salicylic acid from industrial wastewater. Separation and Purification Technology, 145: 63 - 74. 
10. Nataraj, S. K., Roy, S., Patil, M. B., Nadagouda, M. N., Rudzinski, W. E. and Aminabhavi, T. M. (2011). Cellulose-acetate-coated $\alpha$-alumina ceramic composite tubular membranes, for wastewater treatment. Desalination, 281: 348 - 353.

11. Chan, C. H., Chia, C. H., Zakaria, S., Ahmad, I. and Dufresne, A. (2013). Production and characterization of cellulose and nano-crystalline cellulose from Kenaf Core Wood. Bioresources, 8(1): 785 - 794.

12. Segal, L., Creely, J. J., Martin, A. E. and Conrad, C. M. (1959). An empirical method for estimating the degree of crystallinity of native cellulose using the X-ray diffractometer. Textile Research Journal, 29(10): 786 - 794.

13. Chen, Y., Tshabalala, M., A., Gao, J., Stark, N. M. and Fan, Y. (2014). Colour and surface chemistry changes of pine wood flour after extraction and delignification. Bioresources, 9(2): 2937 - 2948.

14. Johar, N., Ahmad, I. and Dufresne, A. (2012). Extraction, preparation and characterization of cellulose fibres and nanocrystals from rice husk. Industrial Crops and Products, 37: 93 - 99.

15. Park, J., Shin, H., Yoo, S., Zoppe, J. O. and Park, S. (2015). Delignification of lignocellulosic biomass and its effect on subsequent enzymatic hydrolysis. Bioresources, 10(2): $2732-2743$.

16. Wells, B., Mccann, M., C., Shedletzky, E., Delmer, D. and Roberts, K. (1994). Structural features of cell walls from tomato cells adapted to grow o the herbicide 2,6-dichlorobenzonitrile. Journal of Microscopy, 173: 155 164.

17. Sheltami, R. M., Abdullah, I., Ahmad, I., Dufresne, A. and Kargarzadeh, H. (2012). Extraction of cellulose nanocrystals from mengkuang leaves (Pandanus tectorius). Carbohydrate Polymers, 88: 772 - 779.

18. Syamani, F. A., Subyakto, S. and Suryani, A. (2015). Changes in oil palm frond fibre morphology, cellulose crystallinity and chemical functional groups during cellulose extraction phases. Chemistry and Materials Research, 7: $105-114$.

19. Neto, W. P. F., Silverio, H. A., Dantas, N. O. and Pasquini, D. (2013). Extraction and characterization of cellulose nanocrystals from agro-industrial residue - Soy hulls. Industrial Crops and Products, 42: 480 - 488.

20. Morán, J. I., Alvarez, V. A., Cyras, V. P. and Vázquez, A. (2008). Extraction of cellulose and preparation of nanocellulose from sisal fibers. Cellulose, 15: $149-159$.

21. Abe, K., Iwamoto, S. and Yano, H. S. (2009). Obtaining cellulose nanofibers with a uniform width of $15 \mathrm{~nm}$ from wood. Biomacromolecules, 8(10): 3276 - 3278.

22. Fahma, F., Iwamoto, S., Hori, N., Iwata, T. and Takemura, A., (2011). Effect of pre-acid- hydrolysis treatment on morphology and properties of cellulose nanowhiskers from coconut husk. Cellulose, 18: $443-450$. 